\title{
Antimicrobial potential of some plant extracts against Candida species
}

\author{
Höfling, JF. ${ }^{\mathrm{a} *}$, Anibal, PC. ${ }^{\mathrm{a}, \mathrm{b}}$, Obando-Pereda, GA. ${ }^{\mathrm{a}}$, \\ Peixoto, IAT. ${ }^{\mathrm{a}, \mathrm{c}}$, Furletti, VF. ${ }^{\mathrm{a}, \mathrm{c}}$, Foglio, MA. ${ }^{\mathrm{b}}$ and Gonçalves, RB. ${ }^{\mathrm{a}}$ \\ aÁrea de Microbiologia e Imunologia, Departamento de Diagnóstico Oral, Faculdade de Odontologia de Piracicaba, \\ Universidade Estadual de Campinas - Unicamp, Av. Limeira, 901, CP 052, CEP 13414-900, Piracicaba, SP, Brazil

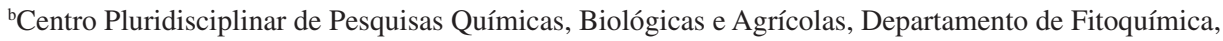 \\ Universidade Estadual de Campinas - Unicamp, Campinas, SP, Brazil \\ ${ }^{\mathrm{c}}$ Centro Pluridisciplinar de Pesquisas Químicas, Biológicas e Agrícolas, Departamento de Microbiologia, \\ Universidade Estadual de Campinas - Unicamp, Campinas, SP, Brazil \\ *e-mail: hofling@fop.unicamp.br \\ Received April 16, 2009 - Accepted January 12, 2010 - Distributed November 30, 2010
}

\begin{abstract}
The increase in the resistance to antimicrobial drugs in use has attracted the attention of the scientific community, and medicinal plants have been extensively studied as alternative agents for the prevention of infections. The Candida genus yeast can become an opportunistic pathogen causing disease in immunosuppressive hosts. The purpose of this study was to evaluate dichloromethane and methanol extracts from Mentha piperita, Rosmarinus officinalis, Arrabidaea chica, Tabebuia avellanedae, Punica granatum and Syzygium cumini against Candida species through the analysis of Minimum Inhibitory Concentration (MIC). Results presented activity of these extracts against Candida species, especially the methanol extract.
\end{abstract}

Keywords: Candida, plant extracts activity, antifungal activity, antimicrobial agents.

\section{Potencial antimicrobiano de extratos de plantas na inibição de leveduras do gênero Candida}

\section{Resumo}

Devido ao aumento da resistência aos antimicrobianos em uso, as plantas medicinais têm sido intensamente estudadas como agentes alternativos para a prevenção de doenças e infecções. A levedura do gênero Candida, por ser um patógeno oportunista, tem sua virulência aumentada ao adquirir resistência aos antifúngicos, desencadeando doenças, principalmente em hospedeiros imunossuprimidos. O propósito deste trabalho foi avaliar os extratos diclorometano e metanol das plantas Mentha piperita, Rosmarinus officinalis, Arrabidaea chica, Tabebuia avellanedae, Punica granatum e Syzygium cumini contra linhagens do gênero Candida através dos testes de Concentração Inibitória Mínima (CIM). Os resultados demonstraram atividade dos extratos sobre as espécies de Candida, particularmente o extrato metanol.

Palavras-chave: Candida, atividade de extratos de plantas, atividade antifúngica, agentes antimicrobianos.

\section{Introduction}

Medicinal plants and corresponding preparations have been used for a wide range of purposes and for many centuries people have been trying to treat diseases as well as alleviate symptoms by using different plant extracts and formulations (Cowan, 1999). Plants such as Mentha piperita (Iscan et al., 2002), Rosmarinus officinalis (Nascimento et al., 2000), Arrabidaea chica (Taylor, 1998), Tabebuia avellanedae (Machado et al., 2003), Punica granatum (Nascimento et al., 2000; Duraipandiyan et al., 2006) and Syzygium cumini (Chandrasekaram and Venkatesalu, 2004) have been used due to their antimicrobial properties.

In the 2000-2006 period, approximately $50 \%$ of new chemical molecules extracted from natural products demonstrated their importance for the development of drugs in the treatment of infectious diseases (Newman and Cragg, 2007). The choice of an appropriate antifungal treatment is important, though limited to a few licensed agents (Provine and Hadley, 2000). The increasing resistance of microorganisms to antimicrobial drugs in use has attracted the attention of the scientific community regarding the search for new cost-effective drugs of natural or synthetic origin (Pai et al., 2004).

Members of the Candida genus are commensal aerobic microorganisms, which are part of the indigenous microbial flora in humans and can be found in the oral cavity and the digestive as well as vaginal tracts (Odds, 1988). They may become opportunistic pathogens causing a number of diseases in immunosuppressive hosts (De Repentigny et al., 2004), 
mainly HIV-positive patients (Erköse and Erturan, 2007). A particular characteristic of Candida is its ability to invade oral mucosa tissues by the development of hyphae, which adhere to tissue surfaces and lead to inflammation (Ellepola and Samaranayake, 2001).

Although the colonisation by Candida albicans is common and causes severe injuries in immunocompromised patients, other Candida species have been isolated from such patients, healthy patients and children with Down's syndrome, such as C. glabrata, C. krusei, C. tropicalis, $C$. lusitaniae, C. parapsilosis, C. guilliermondii (Erköse and Erturan, 2007; Höfling et al., 2001; Ribeiro et al., 2006; Rodrigues et al., 2004) and C. dubliniensis. These yeasts were recognised as the source of mucosal infection in HIV-positive patients and regarded as a significant cause of infections in humans, such as abdominal infections and fungemia (Erköse and Erturan, 2007).

The purpose of this study was to evaluate the potential activity of extracts from six selected plants against ten Candida species.

\section{Material and Methods}

Selected plants: the species Mentha piperita L. (leaves, voucher no. UEC 1253), Arrabidaea chica (Bonpl.) B. Verl. (leaves, voucher no. UEC 1254), Rosmarinus officinalis L. (leaves, voucher no. UEC 1264), Syzygium cumini L.(seeds, voucher no. UEC 143724), Punica granatum L. (fruit, voucher no. UEC 143723) and Tabebuia avellanedae Lor. ex Griseb (bark, voucher no. UEC 1256) were collected from the experimental field of the Research Centre for Chemistry, Biology and Agriculture, State University of Campinas (CPQBA/UNICAMP), Brazil. Voucher specimens were deposited at the Herbarium of the State University of Campinas (UEC) and were identified by Professor Jorge Yoshio Tamashiro, Ph.D.

Preparation of extracts: Each selected plant (5 g) was extracted with $600 \mathrm{~mL}$ of dichloromethane (Labsynth PA) with a Dispersive Extratur (Quimis ${ }^{\circledR}$ Q-252-28 model) and filtered thereafter. The vegetal residue was reextracted with methanol (Labsynth PA). Solvents were evaporated under reduced pressure and dried using a rotary evaporator (Buchi ${ }^{\circledR}$ R-200 model). Crude extracts were monitored by chromatography in Thin Layer in silicagel chromatoplaques (60 F254 Merck 1.05554). The dried plant extracts were dissolved in Tween 20 (Labsynth) and sterile distilled water, filtered through a $0.22-\mu \mathrm{m}$ membrane filter (TPP) and stored at $4{ }^{\circ} \mathrm{C}$ until further use. The extracts were diluted at the moment of use with the concentration ranging from 1 to $0.001 \mathrm{mg} / \mathrm{mL}$.

Microorganisms: The test organisms used were Candida albicans CBS-562, C. dubliniensis CBS-7987, C. parapsilosis CBS-604, C. tropicalis CBS-94, C. guilliermondii CBS-566, C. utilis CBS-5609, C. krusei CBS-573, C. lusitaniae B-06, C. glabrata B-07, C. rugosa B-12, proceeding from the Microbiology and Immunology Laboratory, at the School of Dentistry of Piracicaba (FOP/UNICAMP).

Screening for antimicrobial activities: Preparation of inoculum for susceptibility tests was carried out by microdilution as set forth by the CLSI's M27-A2 recommendation protocol (CLSI, 2002). The yeasts were grown overnight at $37{ }^{\circ} \mathrm{C}$ in Sabouraud Dextrose Agar (Merck) plates, and inocula for the assays were prepared by diluting scrape cell mass in $0.85 \% \mathrm{NaCl}$ solution, adjusted to $0.5 \mathrm{Mc}$ Farland scale and confirmed by spectrophotometric reading at $625 \mathrm{~nm}$. Cell suspensions were finally diluted to $5.0 \times 10^{3} \mathrm{CFU} / \mathrm{mL} .50 \mu \mathrm{L}$ of diluted extract were added in $50 \mu \mathrm{L}$ of RPMI-1640 in microplates (96 wells) $+100 \mu \mathrm{L}$ of microorganisms. After that, the samples were incubated at $37{ }^{\circ} \mathrm{C}$ for $24-48$ hours, in duplicate. Fluconazol was used as control standard in concentrations ranging from $64-0.125 \mu \mathrm{g} / \mathrm{mL}$. The microplates were incubated at $37^{\circ} \mathrm{C}$ for 48 hours.

\section{Results}

All Candida species in the in vitro test presented sensitivity to the plant extracts in use, though not for all extracts (Table 1).

Table 1. In vitro antifungal activity of dichloromethane and methanol extracts $(\mathrm{mg} / \mathrm{mL})$.

\begin{tabular}{|c|c|c|c|c|c|c|c|c|c|c|c|c|}
\hline \multirow{2}{*}{ Microorganisms } & \multicolumn{6}{|c|}{ Dichloromethane extracts } & \multicolumn{6}{|c|}{ Methanol extracts } \\
\hline & AC & MP & SC & TA & RO & PG & AC & MP & SC & TA & RO & PG \\
\hline C. albicans & 0.015 & $\mathrm{R}$ & 0.03 & $\mathrm{R}$ & 0.007 & 0.001 & $\mathrm{R}$ & 0.007 & 0.001 & 0.003 & 0.001 & 0.003 \\
\hline C. dubliniensis & 0.03 & $\mathrm{R}$ & 0.06 & $\mathrm{R}$ & 0.015 & 0.001 & $\mathrm{R}$ & 0.007 & 0.001 & 0.007 & 0.007 & 0.003 \\
\hline C. parapsilosis & 0.015 & $\mathrm{R}$ & 0.007 & $\mathrm{R}$ & 0.03 & 0.001 & $\mathrm{R}$ & 0.003 & 0.001 & 0.003 & 0.003 & 0.003 \\
\hline C. tropicalis & 0.015 & $\mathrm{R}$ & 0.03 & $\mathrm{R}$ & 0.015 & 0.001 & $\mathrm{R}$ & 0.003 & 0.001 & 0.015 & 0.003 & 0.001 \\
\hline C. guilliermondii & 0.015 & $\mathrm{R}$ & 0.007 & $\mathrm{R}$ & 0.007 & 0.001 & $\mathrm{R}$ & 0.001 & 0.001 & 0.001 & 0.003 & 0.001 \\
\hline C. utilis & $\mathrm{R}$ & $\mathrm{R}$ & 0.001 & $\mathrm{R}$ & $\mathrm{R}$ & 0.001 & $\mathrm{R}$ & 0.007 & 0.001 & 0.003 & $\mathrm{R}$ & 0.003 \\
\hline C. krusei & 0.007 & $\mathrm{R}$ & 0.03 & 0.06 & 0.003 & 0.001 & $\mathrm{R}$ & 0.007 & 0.001 & 0.007 & 0.001 & 0.001 \\
\hline C. lusitaniae & 0.007 & $\mathrm{R}$ & 0.03 & $\mathrm{R}$ & 0.007 & 0.001 & $\mathrm{R}$ & 0.007 & 0.001 & 0.003 & 0.001 & 0.001 \\
\hline C. glabrata & $\mathrm{R}$ & $\mathrm{R}$ & 0.001 & $\mathrm{R}$ & $\mathrm{R}$ & 0.001 & $\mathrm{R}$ & 0.003 & 0.001 & 0.001 & $\mathrm{R}$ & 0.003 \\
\hline C. rugosa & 0.007 & $\mathrm{R}$ & 0.03 & $\mathrm{R}$ & 0.001 & 0.001 & $\mathrm{R}$ & 0.003 & 0.001 & 0.003 & 0.001 & 0.003 \\
\hline
\end{tabular}

AC, Arrabidaea chica; MP, Mentha piperita; SC, Syzygium cumini; TA, Tabebuia avellanedae; RO, Rosmarinus officinalis; PG, Punica granatum; R, Resistant. 


\section{Discussion}

Because of the increasing development of drug resistance to human pathogens and the appearance of undesirable effects of certain antifungal agents, the search for new antimicrobial agents is of great concern today (Phongpaichit et al., 2005). A multidisciplinary approach to drug discovery, involving the generation of truly novel molecular diversity from natural product sources combined with total and combinatorial synthetic methodologies, and including the manipulation of biosynthetic pathways, provides the best solution to the current productivity crisis facing the scientific community engaged in drug discovery and development (Newman and Cragg, 2007).

Our results revealed a strong activity of Punica granatum, Syzygium cumini and Rosmarinus officinalis (dichloromethane and methanol extracts), Arrabidaea chica (dichloromethane extract), Mentha piperita and Tabebuia avellanedae (methanol extract), with MIC varying from 0.06 to $0.001 \mathrm{mg} / \mathrm{mL}$; and no or less activity of Arrabidaea chica (methanol extract), Mentha piperita and Tabebuia avellanedae (dichloromethane extract). The methanol extract of A. chica showed activity against yeasts within 24 hours (data not shown). However, these yeasts showed resistance to this extract after 48 hours. Among the 10 yeasts used in this study, the most resistant were C. glabrata and $C$. utilis, and $C$. krusei and $C$. guilliermondii were the most sensitive strains to the tested extracts.

Data obtained from other studies demonstrated positive results for these plants as well. Duraipandiyan et al. (2006) observed inhibitory effects of $P$. granatum, while Nascimento et al. (2000) showed activity of extracts of $P$. granatum, $S$. cumini and $R$. officinalis against Candida albicans. Chandrasekaram and Venkatesalu (2004) reported effectiveness of methanol extract of S. cumini and Portillo et al. (2001) found positive results for the dichloromethane extract of $T$. avellanedae against yeast $C$. albicans, thus validating our results. On the other hand, Duarte et al. (2005) obtained moderate activity testing $M$. piperita oil against $C$. albicans while Duraipandiyan et al. (2006), Portillo et al. (2001) and Dulger and Gonuz (2004) observed resistance of the extracts of S. cumini, T. avellanedae (methanol extract) and $R$. officinalis (ethanolic extract), respectively. Although these results are not in accordance with ours, there may be many other contributing factors, such as the seasonal period when plants are collected.

However, some compounds like tannins ( $P$. granatum, $A$. chica, S. cumini and R. officinalis), anthocyanins (A. chica), flavonoids (A. chica and $R$. officinalis), naphtoquinones (T. avellanedae), menthol and menthone (M. piperita) are known to have antimicrobial properties against microorganisms (Alcerito et al., 2002; Cordeiro et al., 2006; Gershon, 1975; Hussein et al., 1997; Iscan et al., 2002; Wagner et al., 1989). Components like tannins found in plants may act on the cell membrane and precipitin proteins (Nawwar et al., 1994), which turns out to be a target for studies.

The findings presented in this paper indicate that the extracts obtained from the selected plants had anti-Candida activity. Punica granatum and Syzygium cumini extracts exerted strong antifungal activity and can be a source for the development of new therapeutic agents, as they inhibited the growth of Candida. Subsequently, bioguided fractionation shall be conducted on Puninca granatum to identify the active compounds against Candida genus species.

Acknowledgements - This study was supported by the Research Foundation for the State of São Paulo (Fundação de Apoio à Pesquisa do Estado de São Paulo - FAPESP) and the Fund for Education, Research and Extension (Fundo de Apoio ao Ensino, Pesquisa e Extensão - FAEPEX).

\section{References}

ALCERITO, T., BARBO, FE., NEGRI, G., SANTOS, DYAC., MEDA, CI., YOUNG, MCM., CHÁVEZ, D. and BLATT, CTT., 2002. Folicular epicuticular wax of Arrabidaea brachypoda: flavonoids and antifungal activity. Biochemical Systematics and Ecology, vol. 30, p. 677-683.

CHANDRASEKARAN, M. and VENKATESALU, V., 2004. Antibacterial and antifungal activity of Syzygium jambolonum seeds. Journal of Ethnopharmacology, vol. 91, p. 105-108.

Clinical and Laboratory Standards Institute - CLSI, 2002. Método de Referência para Testes de Diluição em Caldo para Determinação da Sensibilidade a Terapia Antifúngica das Leveduras: Norma Aprovada. 2. ed. Wayne, Pa: National Committee for Clinical Laboratory Standards. Norma M27-A2.

CORDEIRO, CHG., SACRAMENTO, LVS., CORREAA, MA., PIZZOLITTO, AC. and BAUAB, TM., 2006. Análise farmacognóstica e atividade antibacteriana de extratos vegetais empregados em formulação para a higiene bucal. Revista Brasileira de Ciências Farmacêuticas, vol. 42., no. 3, p. 395-404.

COWAN, MM., 1999. Plant product as antimicrobial agents. Clinical Microbiology Reviews, vol. 12, no. 4, p. 564-582.

DE REPENTIGNY, L., LEWANDOWSKI, D. and JOLICOEUR, P., 2004. Immunopathogenesis of oropharyngeal candidiasis in human immunodeficiency virus infection. Clinical Microbiology Reviews, vol. 17, p. 729-759.

DUARTE, MCT., FIGUEIRA, GM., SARTORATTO, A., REHDER, VLG. and DELARMELINA, C., 2005. Anti-Candida activity of Brazilian medicinal plants. Journal of Ethnopharmacology, vol. 97, p. 305-311.

DULGER, B. and GONUZ, A., 2004. Antimicrobial activity of certain plants used in Turkish traditional Medicine. Asian Journal of Plant Sciences, vol. 3, no. 1, p. 104-107.

DURAIPANDIYAN, V., AYYANAR, M. and IGNACIMTHU, S., 2006. Antimicrobial activity of some ethnomedicinal plants used by Paliyar tribe from Tamil Nadu, India. BMC Complementary and Alternative Medicine, vol. 6, no. 35, p. 1-7.

ELLEPOLA, ANB. and SAMARANAYAKE, LP., 2001. Adjunctive use of chlorexidine in oral candidoses: a review. Oral Diseases, vol. 7, p. 11-17.

ERKÖSE, G. and ERTURAN, Z., 2007. Oral Candida colonization of human immunodeficiency virus infected subjects in Turkey and its relation with viral load and CD4 ${ }^{+} \mathrm{T}-1 y m p h o c y t e$ count. Mycoses, vol. 50, p. 485-490. 
GERSHON, H., 1975. Fungitoxicity of 1,4-naphtoquinones to Candida albicans. Canadian Journal of Microbiology, vol. 21, p. 1317-21.

HÖFLING, JF., ROSA, EAR., PEREIRA, CV., BORIOLLO, FG. and RODRIGUES, JAO., 2001. Differentiation and numerical analysis of oral yeasts based on SDS-Page profiles. Influence of the culture media on the whole-cell protein extracts. Brazilian Journal of Biology, vol. 61, no. 3, p. 507-516.

HUSSEIN, SAM., BARAKAT, HH., MERFORT, I. and NAWWAR, MAM., 1997. Tannins from the leaves of Punica granatum. Phytochemistry, vol. 45, p. 819-23.

ISCAN, G., KIRIMER, N., KÜRKCÜOGLU, M., BASER, KHC. and DEMIRCI, F., 2002. Antimicrobial screening of Mentha piperita essential oils. Journal of Agricultural and Food Chemistry, vo. 50, p. 3943-3946.

MACHADO, TB., PINTO, AV., PINTO, MCFR., LEAL, ICR., SILVA, MG., AMARAL, ACF., KUSTER, RM. and NETTODOSSANTOS, KR., 2003. In vitro activity of Brazilian medicinal plants, naturally occurring naphtoquinones and their analogues, against methicillin-resistant Staphylococcus aureus. International Journal of Antimicrobial Agents, vol. 21, p. 279-284.

NASCIMENTO, GGF., LOCATELLI, J., and FREITAS, PC. and SILVA, GL., 2000. Antibacterial activity of plant extracts and phytochemicals on antibiotic-resistant bacteria. Brazilian Journal of Microbiology, vol. 31, p. 247-256.

NAWWAR, MAN., HUSSEIN, SAM. and MERFORT, I., 1994. NMR spectral analysis of polyphenols from Punica granatum. Phytochemistry, vol. 36, p. 793-798.

NEWMAN, DJ. and CRAGG, GM., 2007. Natural products as source of new drugs over the last 25 years. Journal of Natural Products, vol. 70, p. 461-477.

ODDS, FC., 1988. Candida and candidoses: a review and bibliography. $2^{\text {nd }}$ ed. London: Basilière Tindall.
PAI, MR., ACHARYA, LD. and UDUPA, N., 2004. Evaluation of antiplaque activity of Azadirachta indica leaf extract gel - a 6-week clinical study. Journal of Ethnopharmacology, vol. 90, p. 99-103.

PHONGPAICHIT, S., SUBHADHIRASAKUL, S. and WATTANAPIROMSAKUL, C., 2995. Antifungal activities of extracts from Thai medicinal plants against opportunistic fungal pathogens associated with AIDS patients. Mycoses, vol. 48, p. 333-338.

PORTILLO, A., VILA, R., FREIXA, B., ADZET, T. and CAÑIGUERAL, S., 2001. Antifungal activity of Paraguayan plants used in traditional medicine. Journal of Ethnopharmacology, vol. 76, p. 93-98.

PROVINE, H. and HADLEY, S., 2000. Preliminary evaluation of a semisolid agar antifungal susceptibility test for yeasts and molds. Journal of Clinical Microbiology, vol. 2, p. 537-541.

RIBEIRO, EL., SCROFERNEKER, ML., CAVALHAES, MS., CAMPOS, CC., NAGATO, GM., SOUZA, NA., FERREIRA, WM., CARDOSO, CG., DIAS, SMS., PIMENTA, FC. and TOLEDO, AO., 2006. Phenotypic aspects of oral strains of Candida albicans in children with Dow's syndrome. Brazilian Journal of Biology, vol. 66, no. 3, p. 939-944

RODRIGUES, JAO., HÖFLING, JF., TAVARES, FCA., DUARTE, KMR., GONÇALVES, RB. and AZEVEDO, RA., 2004. Evaluation of biochemical and serological methods to identify and clustering yeast cells of oral Candida species by CHROMagar test, SDSPage and ELISA. Brazilian Journal of Biology, vol. 64, no. 2, p. 317-326.

TAYLOR, L., 1998. Herbal secrets of the rainforest. Rocklin: Prima Publishing, Inc.

WAGNER, H., KREHER, B., LOTTER, H., HAMBURGER, MO. and CORDELL, GA., 1989. Structure determination of new isomeric naphtha [2,3-b] furan-4,9-diones from Tabebuia avellanedae by the selective-INEPT technique. Helvetica Chimica Acta, vol. 72, p. 659-67. 